УДК 343.3

DOI https://doi.org/10.32837/pyuv.v2i3(28).359

\author{
М. В. Кікалішвілі \\ кандидат юридичних наук, доцент, \\ доцент кафедри кримінального права та кримінологї̈ \\ Київського національного університету ілені Тараса Шевченка
}

\title{
СУЧАСНІ ТЕНДЕНЦІЇ КОРУПЦІЙНОЇ ЗЛОЧИННОСТІ В УКРАЇНІ
}

Корупційна злочинність є однією з головних проблем для будь-якої держави, яка прагне побудувати демократію та в повній мірі дати змогу населенню реалізовувати свої конституційні права. Зовсім не новина, що корупція являє собою реальну загрозу національній безпеці країни та виступає тим чинником, який підриває імідж держави в очах світового співтовариства.

В умовах сучасного життя майже жодна країна не може існувати відокремлено. 3 кожним днем поширюються транснаціональні зв'язки, а світове суспільство стає мультикультурним, оскільки кордони між державами стають все менш відчутними. За таких обставин відбувається не лише людська міграція із перемішуванням різних культур, а й спостерігається активний розвиток та популяризація певних видів злочинності, які вже перестали зосереджуватися лише на деяких країнах, а переросли в глобальні проблеми всього світу. Одним із таких глобальних видів злочинності, що торкається інтересів всіх держав світу, $є$ корупційна злочинність.

Істотного розмаху корупційна злочинність набула ще наприкінці XX століття й з того часу невпинно зростає, підкорюючи собі все більшу кількість осіб зі всіх куточків земної кулі. Наївно було б думати, що хворобливе явище корупції мине Україну. На жаль, наша держава не тільки виявилася зараженою корупцією, а й дала плідне підгрунтя даному явищу для його розвитку та перетворення в одну з головних загроз українській економічній безпеці.

Корупційні прояви пройняли всі ланки суспільних відносин в Україні. За даними авторитетних статистичних порталів, наша держава перебуває на найнижчих щаблях рейтингів щодо рівня корупції в світі та ганебно сусідує з такими нерозвиненими країнами, як Гамбія та М'янма.

А.С. Політова зазначає, що такий високий piвень корупції всередині нашої держави й низьке місце у загальносвітовому рейтингу корупційності держав світу пояснюється тим, що донедавна в нашій країні фактично не було антикорупційного законодавства, яке б відповідало прогресивним міжнародним стандартам [9, с. 153].

Однак не тільки в цьому проблема активного поширення корупційної злочинності на теренах нашої держави. Можна створювати новітні стра- тегії та програми боротьби із корупцією, запозичувати досвід тих країн, що успішно протидіють корупційній злочинності, створювати органи суто антикорупційного спрямування, проте не досягнути жодних позитивних зрушень [7, с. 251]. Це пояснюється тим, що, по-перше будь-яка добра ідея повинна не тільки декламуватися, а й мати чіткий план втілення в життя; по-друге, українська громадськість, на жаль, досить байдуже ставиться до корупції, тому в Україні за роки незалежності так і не вдалося побудувати ідеологію крайньої нетерпимості до корупційної злочинності.

Аби дієво протидіяти корупції та поступово іï викорінити з українського життя, кожному в нашій країні потрібно чітко усвідомлювати ті тенденції корупційної злочинності, які актуальні тут і зараз. Лише розуміючи тенденції розвитку корупційної злочинності, можна виробити дієву антикорупційну стратегію змін. Саме в цьому полягає актуальність даного наукового дослідження. Крім того, актуальність дослідження пояснюється тим, що для успішної євроінтеграції України, чого вкрай прагне український народ, наша держава повинна відповідати вимогам європейської спільноти, де спостерігається низький рівень корупції. Отже, нам необхідно розібратися із тим, які процеси відбуваються із корупційною злочинністю в нашій державі, аби цілеспрямовано зайнятися антикорупційною діяльністю задля швидшої євроінтеграції.

Серед вчених, які присвятили свої праці дослідженню тенденцій корупційної злочинності в Україні, окремо слід виділити таких, як П.П. Андрушко, Ю.В. Баулін, О.Ю. Бусол, В.С. Батиргареєва, О.М. Джужа, О.О. Дудоров, А.П. Закалюк, О.Г. Кальман, М. І. Мельник, Є.В. Невмержицький, Д.Г. Михайленко, М.І. Хавронюк, К.П. Задоя, В.В. Голіна, В.І. Шакун, В.М. Попович.

Оскільки корупційна злочинність та антикорупційне законодавство - це динамічні категоpiï, що постійно змінюються, питання сучасних тенденцій корупційної злочинності потребує постійного вивчення та аналізу з огляду на нові виклики, які кидає сьогодення. Приймаються нові нормативно-правові акти антикорупційного спрямування, з'являються нові суб'єкти протидії корупційній злочинності, тому розробка зазначеного питання вимагає постійної наукової уваги. 
Метою даної статті є дослідження тих тенденцій корупційної злочинності, що спостерігаються на сучасному етапі розвитку України, аналіз тих тенденцій, що зазначені, та виявлення можливих шляхів подолання негативних тенденцій $\mathrm{i}$ закріплення позитивних зрушень щодо протидії корупційним проявам. Задля досягнення поставленої мети необхідно визначитися із дефініціями понять «корупція» та «корупційна злочинність», дослідити головні тенденції корупційної злочинності в Україні, проаналізувати їх особливості, визначитися із позитивними тенденціями щодо запобігання та протидії корупції, а також дійти висновків щодо того, який вектор розвитку треба обрати Україні.

Переходячи до викладення основного матеріалу, зазначимо, що саме являє собою корупція та корупційна злочинність. Відповідно до чинного законодавства України корупцією визнаються дії особи, яка має службові повноваження та певні можливості, що витікають з її службових повноважень, які вона вчинює з метою отримання неправомірної вигоди для себе чи надання неправомірної вигоди для третіх осіб за певну винагороду як матеріального, так і нематеріального характеру [10, ч. 1 ст. 1]. Корупція - це широке теоретичне поняття. Корупційна злочинність входить до загального поняття корупції та конкретизуе ті положення, які характеризують явище корупції. Тобто корупційна злочинність - це ті дії, якими реалізуються теоретичні положення про корупцію на практиці.

Важливо наголосити, що у вітчизняній кримінально-правовій доктрині чітко прослідковуються два періоди щодо визначення того, чи підпадають дії особи під ознаки корупційного злочину. До 25 січня 2015 року питання про те, чи є злочин корупційним, вирішувалося з огляду на законодавче визначення поняття «корупція». Після зазначеної дати в силу вступили зміни, внесені до ст. 45 Кримінального кодексу України (далі - КК України) [4]. Питання корупційності злочину вже вирішувалося $з$ огляду на те, які діяння були передбачені у примітці до зазначеної статті КК України.

Слід наголосити на тому, що як у вітчизняних, так і в зарубіжних наукових колах досі немає єдиного підходу до визначення корупції та корупційної злочинності. Це б значно спростило розробку загальносвітових антикорупційних доктрин та стратегій.

Популярною є думка, відповідно до якої під ознаки корупційності потрапляє будь-яка дія особи із службовими повноваженнями, якщо вона вийшла за рамки своїх безпосередніх обов'язків, навіть якщо не було факту настання неправомірної вигоди для кого-небудь [8, с. 31]. Прихильники подібного підходу ставлять на перший план не отримання чи надання неправомірної вигоди, а зловживання тими повноваженнями, якими наділений службовець. Сам факт цього зловживання - це корупція.

Деяка частина науковців-правників вважає, що корупцію можна визначити як відхилення від певних норм поведінки та професійно-моральних обов'язків.

Отже, можна констатувати наявність істотних розбіжностей у поглядах на визначення корупції та корупційної злочинності, що іноді призводить до відсутності розуміння сутності зазначених явищ.

Неоднорідність підходів до визначення корупції та корупційної злочинності, як доречно зауважує Д.Г. Заброда, призводить до того, що науковці мають лише часткове уявлення про корупцію як про об’єкт наукового дослідження [1].

Більшість вчених наголошує на тому, що корупційна злочинність в Україні характеризується низьким рівнем розслідування корупційних злочинів. Згідно зі статистикою близько половини кримінальних проваджень, відкритих за ознаками корупційного злочину, розслідується та доводиться до судового вироку, який далеко не завжди засуджує корупціонера за очевидної його винуватості. Деякі види корупційних злочинів на території певних областей України взагалі не розслідуються. Здається, що справа тут не в тому, що на даних територіях не відбувається зазначених злочинів, а в тому, що вони не афішуються. Так, на теренах Центральної та Західної України в період з 2015 до 2018 р. не фігурувало жодного злочину, пов'язаного із зловживанням владою або службовим становищем. Цікаво, що при такій статистиці в пресі подекуди виникали тривожні публікації щодо зазначеного виду злочинів у цих регіонах. Домогтися правди тут важко, адже, з одного боку, журналісти можуть проводити замовні розслідування, які не мають обгрунтування, а з іншого - сигнали журналістів можуть бути правдивими, а правоохоронні органи просто покривають впливових службовців, які, очевидно, причетні до корупційних схем.

Загалом з 2014 року згідно з офіційними даними, які періодично оприлюднюються, спостерігається тенденція щодо істотного зменшення вчинення корупційних злочинів в Україні. Так, в Кіровоградській, Волинській, Київській, Сумській, Запорізькій та Миколаївській областях на $51 \%$ зменшалась кількість розслідуваних фактів отримання неправомірної вигоди. Цікаво, що зменшалась саме кількість розслідуваних злочинів, а не загальна кількість вчинюваних злочинів, в чому, на наш погляд, існує принципова різниця. Позитивна тенденція робиться штучно, реальні антикорупційні механізми наразі працюють ще в режимі малої ефективності. Звідки ж узялося таке істотне покращення? Нагадаємо, що такий позитивний антикорупційний інститут, як 
Вищий антикорупційний суд, почав працювати лише восени 2019 року, хоча з перших днів існування його роботу блокували політичні пропагандисти та популісти. Національне антикорупційне бюро України (далі - НАБУ) теж поки що працює більше зі змінним успіхом, адже дійсно великої кількості розслідуваних корупційних злочинів немає. За таких обставин населення стає біднішим, гривня знецінюється, а корупційних злочинів стає менше. Виникає безліч сумнівів. В Україні є чудові умови для існування корупції та їі поширення, адже антикорупційна стратегія, яка на папері виглядає конкурентоспроможною, поки що працює на невелику частину своєї потужності.

Підтвердженням тих сумнівів, що виникають при аналізі ситуації в країні, слугує й те, що близько 70\% українців схильні вважати, що рівень корупції останнім часом не знизився, а підвищився, а позитивна статистика - це справа урядовців, які штучно її створюють і у такий спосіб маніпулюють думкою населення. Українці обгрунтовано вважають, що найбільше скупчення корупціонерів існує серед державних службовців та народних депутатів (близько 68\%). Відсотковий залишок розділили між собою поліцейські, судді та представники податкової служби [11].

Населення країни не вірить у позитивні дані правоохоронців тому, що на побутовому рівні нічого не змінюється, а пересічний громадянин постійно стикається 3 корупційними проявами у дитячих садках, медичних закладах, школах та університетах.

Слід зазначити, що корупційна злочинність в Україні характеризується високим ступенем латентності, тобто такі злочини приховуються від суспільства. Зазначена тенденція цілком зрозуміла, адже, як і будь-який інший вид злочинності, корупційна злочинність передбачає настання кримінальної відповідальності, що не є бажаною для корупціонера. Через розгалужену систему прикриття корупційних злочинів пересічному громадянину неможливо уявити реальний стан корупційності в країні, адже навіть статистичні дані як вітчизняних опитувальників, так і міжнародних не можуть надати повної картини. Досить вірно зауважують деякі вчені, що латентність, про яку стали частіше вести мову в контексті корупційної злочинності, стала актуальним поняттям через підвищення обережності дій з боку корупціонерів та хабарників різного рівня [6, с. 125$]$. З огляду на появу широкого кола суб'єктів суто антикорупційного призначення кожен, хто бере участь у корупційних схемах, почав більш обачно підходити до будь-якої корупційної дії. I дійсно, в Україні наразі функціонує досить розгалужена система органів антикорупційного спрямування. Окрім вже зазначених НАБУ та Вищого антикорупційного суду, в системі кримінальної юстиції нашої держави з'явилися та намагаються побудувати успішну діяльність такі органи, як Національне агентство з питань запобігання корупції та Спеціалізована антикорупційна прокуратура.

Недоліки у роботі цих органів на початкову етапі їх існування, а також високий рівень обережності корупціонерів пояснюються й тим, що корупційні злочини вчиняються службовими особами із владними повноваженнями. Істотний об'єм зазначених повноважень дозволяє корупціонеру не тільки використовувати службові можливості задля незаконного збагачення, а й вчиняти певні дії, спрямовані на захист своєї діяльності та якісне їі прикриття. Тут спостерігається очевидна геометрична прогресія. Що вищою є посада у корупціонера, то більше в нього службових можливостей захистити свої незаконні дії від уповноважених антикорупційних органів. Що більше в нього можливостей для прикриття своєї діяльності, то більше розвивається латентність корупційної злочинності [5, с. 185].

Цікаво дослідити те, відносно вчинення яких саме видів корупційних злочинів, передбачених приміткою до ст. 45 КК України, спостерігається зацікавлення української громадськості. За даними звітів органів кримінальної юстиції, в період з 2013 до 2017 р. найбільше корупційних злочинів відбувалося за ознаками ст. 191 КК України ( «ривласнення, розтрата майна або заволодіння ним шляхом зловживання службовим становищем»). Цей вид корупційної злочинності за звітний період охопив аж $51 \%$ усіх корупційних злочинів в державі [3, с. 146]. Така кількість цих корупційних злочинів яскраво свідчить про те, що в Україні найбільшого розмаху сягає корупційна злочинність так званого елітного блоку - вищих посадовців, службовців та політиків. Пересічний громадянин чи навіть умовний суддя, поліцейський або взагалі не має, або має куди менші можливості привласнювати, розтрачувати майно через зловживання службовим становищем. Точніше, пересічний громадянин взагалі не має такої можливості, адже він не має службового становища.

Якщо сформувати певний топ 3 трьох найбільш розповсюджених злочинів корупційного характеру, то, окрім зазначеного лідера у вигляді ст. 191 КК України, два остатніх місця на п'єдесталі варто віддати злочину, передбаченому ст. $364 \mathrm{KK}$ України («Зловживання владою або службовим становищем»), що становить $19,3 \%$, та злочину, передбаченому ст. 368 КК України («Прийняття пропозиції, обіцянки або одержання неправомірної вигоди службовою особою») - 10,1\%.

Зазначені корупційні злочини склали понад $80 \%$ усіх корупційних злочинів, що вчиняються в державі. Цікаво, що з 2017 року і дотепер ситуація не сильно змінилася. Відсоток зазначених злочинів то трохи зменшується, то трохи збільшуєть- 
ся, але 80\% можна вважати цілком об’єктивною середньою величиною. Виходить, що 80\% корупційних злочинів в нашій державі - це злочини, вчинені в найвищих колах. Інакше кажучи, такі злочини - це політична корупція.

Цікаво, але політична корупція в нашій країні, за відчуттям, збільшується з кожним роком. При зміні однієї політичної верхівки іншою відбувається ще більший сплеск корупційної активності, адже новим лідерам необхідно схопити свій ласий шматок.

Політична складова частина життя дає безліч корупційних можливостей для осіб, що причетні до управління державою. Одним з варіантів корупційної діяльності для політиків є лобіювання певних законів чи змін до законодавства, які потрібні впливовим особам для досягнення якихось власних цілей. Важливо, що корупційну діяльність політиків легко можна замаскувати під політичну доцільність, що робить вкрай важким притягнення винних до відповідальності.

Варіантом корупційної діяльності в політиці слугує й створення спеціальних комісій у тій же Верховній Раді під певні політичні замовлення.

Говорячи про наведені негативні тенденції, пов'язані і з корупційною злочинністю в сучасній Україні, слід відзначити й позитивні фактори, які сприяють поступовому викоріненню корупції 3 життя українців.

Так, найбільш позитивними антикорупційними тенденціями останніх років є розвиток антикорупційного законодавства та збільшення кількості суто антикорупційних органів. Всі нові антикорупційні органи отримали належне нормативно-правове забезпечення, a їх діяльність базується на відповідних нормативно-правових актах. Авжеж, діяльність кожного суб'єкта антикорупційної діяльності з новоприйнятих поки що бажає кращого, але певні позитивні зрушення вже відбуваються. Наприклад, НАБУ вже відзначилося активними діями щодо розслідування корупційних злочинів, вчинених представниками Верховної Ради, що повинно дати сигнал для всіх про те, що рано чи пізно НАБУ стане страшним сном для всіх корупціонерів незалежно від їх статусу та становища.

Загалом, кажучи про те, як змінити негативні тенденції відносно корупційної злочинності, слід зауважити, що українська антикорупційна доктрина повинна приділити прискіпливу увагу таким комплексним запобіжним антикорупційним заходам, як формування ідеології державної служби, забезпечення прозорості державної влади та удосконалення антикорупційного законодавства [2, с. 37-38].

Отже, підводячи підсумок всього дослідження, зазначимо, що на сучасному етапі розвитку України в нашій державі спостерігається низка негативних тенденцій щодо корупційної злочинності. Корупційні злочини погано розслідуються, а позитивна динаміка створюється штучно за відсутності реальних змін. Корупційна злочинність стає дедалі латентнішою та все більше охоплює політичні кола. Очевидно, що, прагнучи до євроінтеграції, Україна повинна протидіяти корупційним проявам та поступово викорінювати явище корупції загалом. Зробити це можливо. Перші кроки для цього вже робляться, оскільки поряд з негативними тенденціями постають і позитивні зрушення в державній антикорупційній політиці. Так, створюються нові антикорупційні органи, розвивається та стає більш розгалуженою система нормативно-правових актів антикорупційного спрямування. За умови неухильного руху за цим напрямком Україна зможе розраховувати на істотну зміну негативних тенденцій щодо корупційної злочинності вже протягом найближчих років.

\section{Jimepamypa}

1. Заброда Д.Г. Сучасні підходи до розуміння сутності корупції. Науковий вісник Юридичної академії Міністерства внутрішніх справ. 2005. № 3 (22). C. 271-279.

2. Зубкова Л.А. Сучасний стан і проблеми запобігання корупції в Україні. Науковий вісник Національної академії внутрішніх справ. 2017. № 3. С. 34-45. URL: http://nbuv.gov.ua/UJRN/Nvknuvs_2017_3_5.

3. Кондратов Д.Ю. Кримінологічна характеристика сучасної корупційної злочинності в Україні. Bicник Крилінологічної асоціацї̈ України. № 2 (19). 2018. C. 141-154. URL: http://dspace.univd.edu.ua/xmlui/ handle/123456789/4438.

4. Кримінальний кодекс України : Закон України від 05.04.2001 р. № 2341-III / Верховна Рада України. Відомості Верховної Ради України (ВВР). 2001. № 25-26. Ст. 131.

5. Кримінологія (Особлива частина) : навч. посіб. / за заг. ред. О.М. Литвинова ; наук. ред. серії O.М. Бандурка. Харків : Харків, нац. ун-т внутр. справ, 2011. 347 c.

6. Маршуба М.О. Корупційна злочинність в Україні: сучасний стан та основні стратегії протидії. Питання боротьби зі злочинністю. 2016. Вип. 31. С. 123-134. URL: http://nbuv.gov.ua/UJRN/Pbzz_2016_31_11.

7. Мейтус В.Ю. Коррупция. Экономический и информационный анализ. Киев : Норапринт, 2003. $257 \mathrm{c.}$

8. Звичаєва корупція? Громадяни та уряд у посткомуністичній Європі / Вільям Мілер, Осе Гределанд, Тетяна Кошечкіна ; пер. Дмитро Скляренко. Київ : Видавництво «К.І.С.», 2004. 328 с.

9. Політова А.С. Корупційна злочинність в Україні : стан і тенденції Вісник Луганського державного університету внутрішніх справ імені Е.О. Дідоренка. 2016. Вип. 2. С. 152-162. URL: http://nbuv.gov.ua/ UJRN/Vlduvs_2016_2_17.

10. Про запобігання корупції : Закон України від 14.10.2014 р. № 1700-VII / Верховна Рада України. Відомості Верховної Ради (BВP). 2014. № 49. Ст. 2056.

11. Українці невдоволені рівнем боротьби з корупцією - дослідження Transparency International. URL: https://ukrainian.voanews.com/a/global-corruptionbarometer $/ 3598555 . \mathrm{html}$. 


\section{Анотація}

Кікалішвілі М. В. Сучасні тенденції корупційної злочинності в Україні. - Стаття.

Стаття присвячена розгляду сучасних тенденцій корупційної злочинності в Україні.

У статті встановлено, що саме являє собою корупція та наведено різні погляди на визначення цього поняття, зауважено, що неоднорідність підходів щодо визначення корупції та корупційної злочинності призводить до того, що науковці мають лише часткове уявлення про корупцію як про об'єкт наукового дослідження.

Автором розкриваються головні тенденції щодо корупційної злочинності в Україні та аналізуються причини тієї чи іншої тенденції.

У статі звертається увага, що в сучасній Україні дедалі частіше створюється штучна статистика щодо зменшення кількості корупційних злочинів, а загальна ситуація із корупцією не змінюється. Антикорупційні реформи ще не працюють на повну потужність. Зауважується, що корупційна злочинність в Україні характеризується високим рівнем латентності, що пояснюється підвищеним бажанням корупціонерів захистити себе від настання можливої відповідальності.

Визначено, що Україна йде правильним шляхом, проводячи зміни в своїй антикорупційній доктрині, необхідні для успішної євроінтеграції. За умови системного підходу до викорінення корупційної злочинності зі своїх терен Україна зможе подолати негативні тенденції щодо поширення корупційної злочинності та їі панівного стану в політичних колах та поступово дійти до рівня розвитку передових держав світу.

Ключові слова: корупція, корупційна злочинність, тенденції, латентність корупційної злочинності, політична корупція, антикорупційні органи.

\section{Summary}

Kikalishvili M. V. Current trends in corruption criminality in Ukraine. - Article.

The article is devoted to consideration of modern tendencies of corruption criminality in Ukraine.

It is established what exactly corruption is and different views on the definition of the mentioned concept are given in the article. It is noted that the divergent approaches to the definition of corruption and corruption criminality lead to the fact that scientists have only a partial idea of corruption as the object of scientific research.

The author reveals the main modern tendencies concerning corruption crime in Ukraine and analyzes the reasons of this or that tendency.

The article draws attention to the fact that in today's Ukraine more often artificial statistics are being created regarding the reduction of corruption crimes, while the overall situation with corruption does not change and anti-corruption reforms are not yet working at full capacity. It is noted that corruption in Ukraine is characterized by a high level of latency, which is explained by the increased desire of corrupt officials to protect them from possible liability.

As a result, it has been determined that Ukraine is going the right way making changes in its anti-corruption doctrine, which are necessary for successful European integration. With a systematic approach to eradicating corruption from its territory, Ukraine is able to overcome the negative trends in the spread of corruption and its dominance in political circles and gradually reach the level of development of the world's leading countries.

Key words: corruption, corruption criminality, trends, latency of corruption, political corruption, anticorruption bodies. 